\title{
TINGKAT KEPUASAN KONSUMEN WHAT'S UP CAFE MANADO
}

\author{
Virjinia Tulungen \\ Theodora Maulina Katiandagho \\ Agnes Estephina Loho
}

\begin{tabular}{ll}
\hline Naskah diterima melalui Website Jurnal Ilmiah agrisosioekonomi@ unsrat.ac.id & : Rabu, 9 Oktober 2019 \\
Disetujui diterbitkan & $:$ Kamis, 24 Oktober 2019 \\
\hline
\end{tabular}

\begin{abstract}
The purpose of this study was to determine the level of consumer satisfaction What's Up Cafe Manado regarding products, prices, places, and services. This research was conducted for 2 months from February to March 2019. Determination of the sample using accidental sampling technique. Data collected in this study are primary data and secondary data. Primary data were collected from direct interviews with 30 respondents (consumers) using a questionnaire with a Likert scale. Secondary data were obtained from local bookstores and the internet. From the internet using Google Scholar to get books, scientific journal articles and theses from other universities related to research topics on the level of consumer satisfaction. The results showed that the level of consumer satisfaction of What's Up Cafe Manado overall was classified as very satisfied by $82.04 \%$. In detail, the level of customer satisfaction for What's Up Cafe for the very satisfied category was $84.45 \%$ for product variables, $83.99 \%$ for prices, and $80.33 \%$ for places. For the satisfied category, the service variable is $79.99 \%{ }^{*}{ }^{*}$ prm*
\end{abstract}

Keywords: Satisfaction, consumers, What's Up Cafe, Likert scale

\begin{abstract}
ABSTRAK
Tujuan dari penelitian ini adalah untuk mengetahui tingkat kepuasan konsumen What's Up Cafe Manado menyangkut produk, harga, tempat, dan layanan. Penelitian ini dilakukan selama 2 bulan mulai bulan Februari sampai bulan Maret 2019. Penentuan sampel menggunakan teknik pemilihan sampel secara kebetulan (accidental sampling). Data yang dikumpulkan dalam penelitian ini adalah data primer dan data sekunder. Data primer dikumpulkan dari wawancara langsung dengan 30 responden (konsumen) dengan menggunakan kuesioner yang menggunakan skala likert. Data sekunder diperoleh dari toko buku lokal dan internet, dari internet menggunakan google cendekian untuk mendapatkan buku, artikel jurnal ilmiah dan skripsi dari perguruan tinggi lain yang berkaitan dengan topik penelitian tentang tingkat kepuasan konsumen. Hasil penelitian menunjukkan bahwa tingkat kepuasan konsumen What's Up Cafe Manado secara keseluruhan tergolong kategori sangat puas sebesar $82,04 \%$. Secara terinci, tingkat kepuasan pelanggan What's Up Cafe untuk kategori sangat puas adalah $84,45 \%$ untuk variabel produk, $83,99 \%$ untuk harga, dan $80,33 \%$ untuk tempat. Untuk kategori puas, variabel layanan adalah 79,99\%."eprm*
\end{abstract}

Kata kunci: Kepuasan, konsumen, What's Up Cafe, skala Likert 


\section{PENDAHULUAN}

\section{Latar Belakang}

Keberhasilan perusahaan dalam mencapai kinerja yang optimal ditentukan oleh seberapa besar perusahaan mampu untuk berubah, dan terus bertahan serta berkompetisi dalam persaingan bisnis. Dalam persaingan yang berkelanjutan ini, perusahaan memiliki keunggulan dengan menghasilkan produk dan jasa yang benar-benar memenuhi harapan dan memuaskan konsumen. Semakin banyak perusahaan bersaing dalam suatu usaha atau bisnis akan mempertinggi persaingan yang terjadi Supranto (2006). Meningkatnya bisnis makanan dan minumam, menyebabkan terjadinya persaingan bertambah ketat. Dalam kondisi persaingan yang semakin ketat setiap perusahaan harus mampu bertahan hidup, bahkan harus dapat berkembang. Oleh sebab itu setiap perusahaan dituntut untuk memiliki kepekaan terhadap setiap perubahan yang terjadi sehingga dapat mengikuti selera konsumen sebagai tujuan utama dari perusahaan. Persaingan yang semakin ketat, dimana semakin banyak produsen yang terlibat dalam pemenuhan dan keinginan konsumen, menyebabkan setiap perusahaan harus menempatkan orientasi pada kepuasan pelanggan sebagai tujuan utama (Tjiptono dalam Sari, 2012).

Kepuasan pelanggan merupakan hal yang penting bagi setiap perusahaan jasa/barang pada perusahaan, kepuasan dapat diartikan sebagai perasaan puas, rasa senang dan kelegaan seseorang dikarenakan

mengkonsumsi suatu produk atau jasa untuk mendapatkan pelayanan suatu jasa (Aaker, 2013).

Ditinjau dari kehidupan masyarakat Kota Manado yang kebiasaannya makan-makan, maka Kota Manado berpotensi mengembangkan bisnis cafe. Memberikan peluang yang harus ditangkap oleh perusahaan-perusahaan bisnis makanan siap saji. Dimanado khususnya kawasan megamas terdapat cafe siap saji diantaranya cafe Basombar, Rumah Kopi Bily, Uncle Sams's, dan masih banyak lagi. Cafe-cafe ini merupakan usaha dalam bisnis kuliner yang bertujuan meningkatkan penjualan lewat makanan dan minuman. Bisnis cafe saat ini terrmasuk salah satu bisnis yang paling digemari. Cafe merupakan salah satu bagian yang bergerak dalam bisnis kuliner yang sudah dikenal masyarakat diantaranya What's Up Cafe.

What's Up Cafe merupakan usaha dalam bisnis kuliner yang bertujuan meningkatkan penjualan lewat makanan dan minuman yang ada dalam perusahaan yang ditawarkan untuk memenuhi kebutuhan dan kepuasan konsumen. Setiap cafe berusaha menonjolkan keunikan mereka masing-masing, baik dalam penyajian maupun dalam menu yang disediakan. Masyarakat Manado yang dikenal sebagai masyarakat yang hobi makan menyebabkan bisnis cafe bertumbuh pesat. Cafe What's Up salah satu cafe yang menyajikan makanan seperti mie instan, roti bakar, dessert, dan What's Up Drink. Meski menu utama di cafe ini adalah indomie, dimodifikasi dengan versi yang lebih sehat, yakni tanpa menggunakan bumbu instan yang terdapat didalam kemasan mie tersebut. Masakannya memakai racikan bumbu tersendiri membuat makanan yang disajikan lebih otentik sehingga memiliki rasa yang berkualitas dan berciri khas What's Up cafe. Harga yang diberikan oleh What's Up cafe relatif murah, karena disesuaikan dengan kantong pelajar, mahasiswa, dan karyawan. What's Up Cafe mulai beroprasi pukul 07.00 pagi hingga 23.00 malam, berlokasi di kawasan Megamas Blok 3C, Jalan Sam Ratulangi, Manado, Sulawesi Utara.

Keunikan dari What's Up cafe interiornya mengikuti tren yang menarik perhatian konsumen sehingga datang ke What's Up cafe. Mulai dari desain dinding What's Up cafe yang menarik. What's Up cafe mengusung dekorasi terbuka tanpa adanya pembatas ruangan satu ke ruangan lainnya dan memiliki 2 lantai. What's Up cafe memberikan fasilitas-fasilitas yang dapat menunjang kenyamanan dan kepuasan konsumen. Seperti wifi gratis dan menyediakan live music yang memanjakan konsumen sehingga konsumen dapat menikmati musik yang dimainkan dan tentunya membuat konsumen merasa santai disaat sedang menikmati makanan dan minuman diiringi oleh musik.

Beberapa macam cafe yang ada, tidak semuanya bisa langsung memuaskan konsumen, maka produk yang dipasarkan harus diimbangi dengan manajemen hubungan pelanggan dan penetapan harga jual produk. Menurut Tjiptono dan Chandra (2011), ada beberapa faktor utama kepuasan konsumen diantaranya produk dan kualitas pelayanan.. Melihat fenomena yang terjadi ingin diketahui kualitas What's Up cafe. Oleh karena itu peneliti tertarik untuk meneliti tingkat kepuasan konsumen di What's Up cafe Manado. 


\section{Konsep Kepuasan Konsumen}

Kepuasan adalah tanggapan pelanggan atas terpenuhnya kebutuhan. Kepuasan dapat diartikan sebagai upaya pemenuhan sesuatu atau membuat sesuatu memadai Rahayu (2005). Sedangkan Band dalam Nasution (2005) mengatakan bahwa kepuasan tercapai ketika kualitas pelayanan yang diberikan melebihi harapan, keinginan dan kebutuhan konsumen. Sebaliknya, bila kualitas tidak memenuhi dan melebihi harapan, keinginan dan kebutuhan komsumen maka kepuasan tidak tercapai. Lebih jauh lagi dikatakan bahwa kepuasan merupakan fungsi dari persepsi atau esan atas kinerja dan harapan. Kinerja dibawah harapan maka konsumen tidak puas sebaliknya jika kinerja memenuhi harapan konsumen puas, dan jika kinerja melebihi harapan konsumen merasa sangat puas atau senang. Banyaknya perusahaan memfokuskan pada kepuasan tinggi, karena para konsumen yang kepuasannya hanya biasa-biasa saja mudah untuk berubah pikiran bila mendapatkan tawaran lebih baik.

\section{Komponen Kepuasan Konsumen}

Menurut Giese dan Cote (2000) sekalipun banyak definisi kepuasan konsumen, namun secara umum tetap mengarah kepada tiga komponen utama, yaitu :

1. Respon : Tipe dan identitas

Kepuasan konsumen merupakan respon emosional dan juga kognitif. Intensitas responnya mulai dari sangat puas dan menyukai produk sampai sikap yang apatis (acuh/tidak perduli) terhadap produk tertentu.

\section{Fokus}

Fokus pada tampilan objek disesuaikan pada beberapa standar. Nilai standar ini secara langsung berhubungan dengan produk, konsumsi, keputusan berbelanja, penjual dan toko.

\section{Waktu Respon}

Respon terjadi pada waktu tertentu, antara lain setelah konsumsi, setelah pemilihan produk atau jasa berdasarkan pengalaman akumulatif. Durasi kepuasan mengarah kepada berapa lama respon kepuasan itu berakhir.

\section{Konsep Memuaskan Konsumen}

Strategi kepuasan pelanggan, diharapkan dapat meningkatkan pangsa pasar, penjualan dan jumlah pelanggannya. Berikut strategi kepuasan pelanggan yang dapat diterapkan pada perusahaan jasa menurut Tjiptono (2005) :
1. Strategi Manajemen Ekspektasi Pelanggan

Ekspektasi pelanggan dibentuk dan didasarkan pada sejumlah faktor, seperti pengalaman berbelanja dimasa lalu, opini teman dan kerabat, serta informasi dan janji - janji perusahaan dan para pesaingnya.

2. Relasi Pemasaran dan Manajemen

Relasi pemasaran dan manajemen merupakan cara berpikir mengenai pelanggan, pemasaran, dan penciptaan nilai, bukan sekedar serangkaian alat, teknik dan taktik. Dengan kata lain, relasi pemasaran dan manajemen merupakan ancangan integratif atau holistik yang memperkokoh kompetensi pemasaran perusahaan.

\section{After Marketing}

Tahap ini menekankan pentingnya aktivitas pemasaran dan komunikasi setelah transaksi pembelian. Khususnya dalam rangka memberikan keyakinan setelah tahap pembelian (agar konsumen yakin bahwa keputusan pembelian yang dilakukannya benar - benar bijaksana) dan membangun loyalitas merek.

\section{Strategi Retensi Pelanggan}

Strategi retensi pelanggan difokuskan pada teknik - teknik yang digunakan untuk mempertahankan pelanggan agar pelanggan tidak beralih pada pemasok atau perusahan jasa yang lain.

\section{Superior Customer service}

Pelayanan pelanggan superior diwujudkan dengan cara menawarkan layanan yang lebih baik dibandingkan para pesaing.

\section{Strategi Pemasukan atau Infusi Teknologi}

Teknologi bisa dimanfaatkan secara efektif untuk meningkatkan dan memuaskan pengalaman layanan kepuasan pelanggan.

\section{Strategi Penanganan Komplain Secara Efektif}

Di dalam industri yang sama - sama bergerak dibidang jasa, wajib untuk menanggapi komplain dari para pelanggannya, agar dapat mengetahui tingkat kepuasan pelanggan. Pada hakikatnya ada dua tujuan utama pelanggan menyampaikan komplain. Pertama, untuk menutupi kerugian ekonomis, dan kedua adalah untuk memperbaiki citra diri (self-image). 


\section{Strategi Pemulihan Layanan}

Dalam perusahaan jasa, seberapa kerasnya usaha penyedia jasa, tetap saja kekecewaan atau tidak kepuasan pelanggan tidak terhindarkan. Maka dari itu, taktik taktik pemulihan layanan sangat dibutuhkan guna memberikan dampak yang positif terhadap nilai kepuasan pelanggan, minat pembelian ulang, loyalitas dan komitmen pelanggan, juga persepsi pelanggan terhadap keadilan pelayanan jasa. Kedelapan strategi ini sangat berhubungan erat, bahkan kadang kala ada elemen-elemen yang overlapping.

\section{Konsep Pengukuran Kepuasan Konsumen}

Menurut Kotler (2000), ada empat yang digunakan untuk mengukur kepuasan pelanggan, yaitu :

\section{Sistem Keluhan dan Saran}

Perusahaan memberikan kesempatan yang luas kepada para pelanggannya untuk menyampikan saran dan keluhan. Informasiinformasi ini dapat memberikan ide-ide cemerlang bagi perusahaan dan memungkinkannya untuk bereaksi secara tanggap dan cepat untuk mengatasi masalahmasalahnyang timbul.

\section{Pelanggan Bayangan (Ghost Shopping)}

Salah satu cara untuk memperoleh gambaran mengenai kepuasan pelanggan adalah dengan memperkerjakan beberapa orang untuk berperan atau bersikap sebagai pelanggan/pembeli potensial produk perusahaan dan pesaung. Kemudian mereka melaporkan temuan-temuannya mengenai kekuatan dan kelemahanproduk perusahaan dan pesaing berdasarkan pengalaman mereka dalam membeli produk-produk tersebut.

\section{Analisis pelanggan yang hilang (Lost Customer} Analysis)

Metode ini perusahaan harus menghubungi para pelanggan yang telah berhenti membeli produk karena telah berpindah pada perusahaan pesaing. Selain itu perusahaan dapat menanyakan sebab-sebab berpindahnya pelanggan ke perusahaan lain.

\section{Survei Kepuasan Pelanggan}

Sesekali perusahaan perlu melakukan survei kepuasan pelanggan terhadap kualitas jasa atau produk perusahaan tersebut. Servei ini dapat dilakukan dengan penyeberan kuisioner oleh karyawan perusahaan kepada para pelanggan. Melalui servei tersebut, sehingga perusahaan dapat melakukan perbaikan pada hal yang dianggap kurang oleh pelanggan.

\section{Strategi Pemasaran}

Menjalankan sebuah bisnis, strategi pemasaran merupakan poin yang terpenting. Bisa dikatakan strategi pemasaran yang baik merupakan kunci keberhasilan penjualan produk. Strategi pemasaran adalah pola pikir pemasaran yang akan digunakan untuk mencapai tujuan pemasarannya. Strategi pemasaran berisi strategi spesifik untuk pasar sasaran, penetapan posisi, bauran pemasaran dan besarnya pengeluaran pemasaran Kotler (2004). Dalam strategi pemasaran terdapat dasar tindakan yang mengarah pada kegiatan pemasaran perusahaan tersebut. Kondisi pesaing dan lingkungan yang biasa selalu berubah-ubah dengan harapan dapat tercapainya suatu tujuan yang diinginkan.

Strategi dipakai perusahaan, dengan membuat kondisi pasar dan menilai posisi dipasar tersebut. Tujuannya agar kegiatan pemasaran apa yang pas dapat ditetapkan dipasar. Dengan kata lain strategi pemasaran merupakan alat fundamental yang direncanakan untuk mencapai perusahaan dengan mengembangkan keunggulan bersaing yang berkesinambungan melalui pasar yang dimasuki dan program pasar yang digunakan untuk melayani pasar sasaran tersebut.

\section{Perumusan Masalah}

Permasalahan dalam penelitian ini yaitu bagaimana tingkat kepuasan konsumen yang diberikan oleh What's Up Cafe.

\section{Tujuan Penelitian}

Tujuan penelitian ini adalah untuk mengetahui tingkat kepuasan konsumen What's Up Cafe Manado.

Manfaat adalah :

1. Sebagai masukan dan pertimbangan bagi What's Up Cafe Manado dalam mengembangkan strategi menghadapi persaingan, sehingga dapat dijadikan pertimbangan dalam pengembangan dimasa yang akan datang.

2. Sebagai bahan masukan dan referensi bagi pihak-pihak yang berkepentingan terhadap masalah kepuasan konsumen. 


\section{METODE PENELITIAN}

\section{Waktu dan Tempat Penelitian}

Penelitian ini dilaksanakan di What's Up Cafe Manado. Jangka waktu penelitian yaitu selama 1 (satu) bulan, yakni sejak bulan Februari sampai dengan Maret 2019.

\section{Metode Pengumpulan Data}

Data yang digunakan dalam penelitian ini adalah data primer dan data sekunder. Data primer diperoleh dengan memberikan pertanyaan langsung kepada konsumen, dengan menggunakan kuisioner sebagai pengumpulan data. Sedangkan data sekunder diperoleh dari cafe tersebut yang terkait dalam penelitian ini, seperti sejarah cafe. Metode pengumpulan data dilakukan dengan metode wawancara.

\section{Metode Pengambilan Data}

Pengambilan sampel menggunakan metode Accidental sampling yaitu penentuan sampel secara kebetulan, yaitu siapa saja yang secara kebetulan bertemu dengan peneliti di What's Up Cafe Manado dapat digunakan sebagai sampel. Peneliti akan memilih siapa saja yang ditemui dilokasi penelitian dan bersedia untuk dijadikan sebagai responden. Responden ini adalah konsumen yang bersedia untuk diwawancarai dengan kuisioner. Pengambilan sampel difokuskan pada konsumen yang membeli produk What's Up. Pengambilan sampel dilakukan pada hari biasa dan hari libur. Jumlah sampel sebanyak 30 responden.

\section{Konsep Pengukuran Variabel}

Variabel-variabel yang akan diukur dalam penelitian ini adalah :

1. Karakteristik Responden, mencakup:

1) Jenis Kelamin (laki-laki/perempuan).

2) Umur : Usia responden sejak responden dilahirkan.

3)Pendidikan terakhir : Lamanya responden duduk dibangku sekolah (SLTP/SMU/Diploma/Sarjana).

4) Pekerjaan : Profesi responden pada saat wawancara dilaksanakan.

2. Tingkat kepuasan konsumen What's Up cafe, pengukuran tingkat kepuasan dilihat dari empat aspek sebagai berikut :
1) Produk, berkaitan dengan kualitas dan kuantitas produk yang ditawarkan produsen. Indikator-indikatornya sebagai berikut :

a) Kerapian dalam penyajian

b) Tampilan fisik produk

c) Cita rasa produk

d) Keragaman produk

2) Harga, berkaitan dengan jumlah uang yang dikeluarkan konsumen dalam memperoleh produk. Indikator-indikatornya adalah :

a) Keterjangkauan harga

b) Kesesuaian harga dengan isi

c) Kesesuaian harga dengan cita rasa

3) Tempat, berkaitan dengan vasilitas yang disediakan produsen. Indikator-indikatornya sebagai berikut :
a) Kebersihan ruangan
b) Kenyamanan ruangan
c) Tampilan fisik ruangan
d) Kelengkapan sarana dan fasilitas yang dimiliki

4) Pelayanan, berkaitan dengan pelayanan yang memuaskan konsumen. Indikatorindikatornya sebagai berikut :

a) Keandalan (Reliability), yaitu kecepatan dalam menyediakan produk.

b) Daya tanggap (Responsiveness), yaitu kesiapan karyawan dalam memberikan pelayanan dan menangani keluhan para konsumen.

c) Keyakinan (Assurance), pengetahuan karyawan pada produk yang dijual.

d) Penampilan fisik (Tangible), yaitu penampilan fisik dari karyawan.

e) Empati (Emphaty), yaitu keramahan karyawan dalam melayani konsumen.

\section{Metode Analisis Data}

Analisis data yang digunakan dalam penelitian ini adalah menggunakan analisis deskriptif dengan menggunakan skala pengukuran sikap yaitu skala likert.

\section{Skala Likert}

Skala likert (likert scale) adalah teknik pengukuran yang paling luas digunakan dalam riset pemasaran. Uji skala likert memungkinkan responden menjawab dalam berbagai tingkatan setiap butir yang menguraikan jasa atau produk yaitu dengan memberikan sebagai berikut :

Skor $1=$ Sangat Tidak Puas

Skor $2=$ Tidak Puas

Skor $3=$ Netral

Skor $4=$ Puas

Skor 5 = Sangat Puas 
Dengan cara perhitungan skor masingmasing pertanyaan: jumlah skor tiap kriterium $\mathrm{x}$ jumlah responden.Jadi:

$\mathrm{S} 1=1 \times 30=30$

$\mathrm{S} 2=2 \times 30=60$

$\mathrm{S} 3=3 \times 30=90$

$\mathrm{S} 4=4 \times 30=120$

$\mathrm{S} 5=5 \times 30=150$

Jumlah skor ideal untuk setiap pertanyaan $($ skor tertinggi $)=150$, jumlah skor terendah $=30$. Dengan interpretasi nilai:

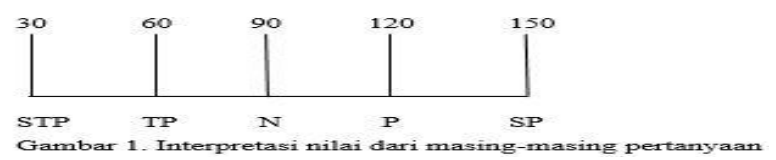

Cara perhitungan skor keseluruhan untuk mengetahui kepuasan konsumen : Jumlah Skor keseluruhan kriterium $=$ capaian jumlah skor $\mathrm{X}$ jumlah responden $\mathrm{X}$ jumlah instrument pertanyaan.

$\mathrm{S} 5=5 \times 30 \times 15=2.250$

$\mathrm{S} 4=4 \times 30 \times 15=1.800$

$\mathrm{S} 3=3 \times 30 \times 15=1.350$

$\mathrm{S} 2=2 \times 30 \times 15=900$

$\mathrm{S} 1=1 \times 30 \times 15=450$

Jumlah skor ideal untuk keseluruhan pertanyaan $=2.250$ (sangat puas), jumlah skor terendah $=450$ (sangat tidak puas).

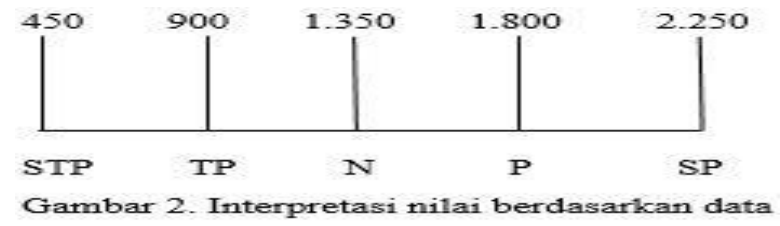

\section{Analisis Indeks Kepuasan Konsumen}

Indeks kepuasan konsumen adalah data dan informasi tentang tingkat kepuasan pelanggan yang diperoleh dari hasil pengukuran kualitatif dan kuantitatif atas pendapat pelanggan dalam memperoleh pelayanan publik dengan membandingkan antara harapan dan kenyataan.

Menurut Supranto (2006) Indeks Kepuasan Konsumen Menggunakan rumus :

$$
I K K=\frac{\text { Jumlah skor hasil pengukuran data }}{\text { Jumlah skor ideal (tertinggi) }} \times 100 \%
$$

Dengan indeks kepuasan konsumen yaitu:

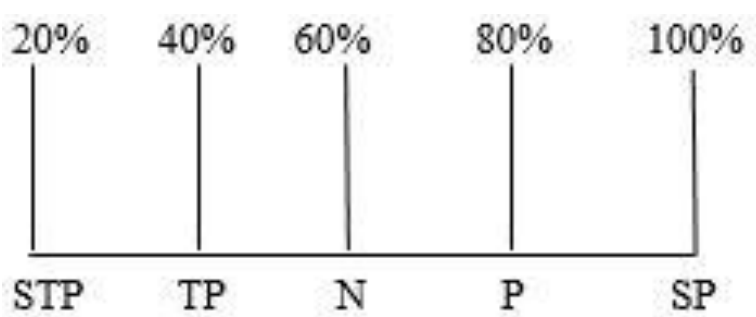

\section{Gambar 3. Persentase Kepuasan Konsumen}

Keterangan : kriteria interpretasi skor

Angka 0\% - 20\% = Sangat Tidak Puas

Angka 20\% - 40\% = Tidak Puas

Angka $40 \%-60 \%=$ Netral

Angka 60\% - 80\% = Puas

Angka 80\% - 100\% = Sangat Puas

\section{HASIL DAN PEMBAHASAN}

\section{Deskripsi Umum Tempat Penelitian \\ Sejarah Berdirinya What's Up Cafe Manado}

What's Up Cafe merupakan salah satu bisnis yang bergerak dibidang kuliner pertama kali dibuka di Kawasan Komplek Mega Mas Blok 3C, Manado. What's Up Cafe berdiri pada tanggal 17 Desember 2017. Cafe What's Up yang dikelola oleh Direktur Marketing Ayu Zulia Safirah dan Novy Salitara sebagai Manager Whats Up Cafe Manado dan cafe ini merupakan bisnis keluarga.

What's Up Cafe menawarkan beberapa menu yaitu indomie dengan berbagai varian rasa seperti (special What's Up, oseng mercon, milky curry, tomyum seafood, chicken rica-rica, carbonara, martabak indomie, chicken balado, chicken teriyaki, indomie bolognese, goring mercon, beef bulgogi, burger steak, black pepper beef, chicken mushroom), What's Up rice dengan varian rasa (nasi goreng anak kost, nasi goring gentong, special fried, chicken ricarica,chicken teriyaki, oseng mercon, black pepper beef, chicken mush room, beef bulgogi), What's Up snack dengan varian rasa seperti (banana nugget, French fries, tasty fried enoki,uwel-uwel), What's Up toast dengan varian rasa (chocolate, cheese, chocolate cheese, greentea, ovomaltine, milo, egg corned beef, cheese corned beef, special salty), What's Up pancake dengan varian rasa (original, vanilla, chocolate, greentea purple, nutella), What's Up frape and tea dengan varian rasa (strawberry, blueberry, choco beng, red velvet,dark cocoa, avocado, greentea, taro frappe, ice lychee, the tarik, lemon tea, greensand), dan What's Up drink dengan varian rasa (original coffe, ice mocca, milky, ice milo, hot milo, pepsi, fanta, sprite,cola). What's Up Cafe mengambil tema "The Real Hangout Place" untuk menjadi tempat nongkrong yang menyediakan menu makanan dan minuman dengan harga yang sesuai dengan kantong mahasiswa dengan pangsa pasar khusus anak muda. 


\section{Karakteristik Responden}

Jumlah responden dalam penelitian ini berjumlah 30 responden yang menjadi konsumen What's Up Cafe Manado. Selanjutnya akan dijelaskan sebagai berikut:

\section{Berdasarkan Jenis Kelamin}

Karakteristik responden dalam penelitian ini berdasarkan jenis kelamin:

\begin{tabular}{cccc}
\multicolumn{4}{c}{ Tabel 1. Karakteristik Responden Berdasarkan Jenis Kelamin } \\
\hline No & Jenis Kelamin & Responden & Persentase (\%) \\
\hline 1 & Laki-laki & 10 & 33,0 \\
2 & Perempuan & 20 & 67,0 \\
\hline & Total & $\mathbf{3 0}$ & $\mathbf{1 0 0}$
\end{tabular}

Sumber : Diolah dari data primer, 2019

Tabel 1 menunjukkan bahwa sebagian besar responden perempuan sebanyak 20 responden dengan persentase $67,0 \%$ sedangkan responden laki-laki sebanyak 10 responden dengan jumlah persentase $33,0 \%$.

\section{Berdasarkan Umur}

Tabel 2 menunjukkan bahwa jumlah responden terbanyak pada umur antara 20-25 Tahun yaitu 18 orang dengan persentase sebesar $60,0 \%$ sedangkan jumlah responden terendah ada pada umur antara 15-19 tahun dengan responden $40,0 \%$.

Tabel 2. Karakteristik Responden Berdasarkan Umur

\begin{tabular}{cccc}
\hline No & Usia & Responden & Persentase (\%) \\
\hline 1 & 15-19 Tahun & 12 & 40,0 \\
2 & 20-25 Tahun & 18 & 60,0 \\
\hline \multicolumn{2}{l}{ Total } & $\mathbf{3 0}$ & $\mathbf{1 0 0}$
\end{tabular}

Sumber : Diolah dari data primer, 2019

Hal ini disebabkan karena, What's Up Cafe berfokus pada kaum milenial. Hasil deskripsi ini menunjukkan bahwa sebagian besar konsumen What's Up cafe Manado adalah anak muda.

\section{Pendidikan Responden}

Berdasarkan pendidikan terakhir ini berguna untuk pendukung analisis di mana konsumen terbanyak yang mempercayakan What's Up Cafe Manado berdasarkan usia adalah anak muda. Berikut ini adalah deskripsi responden dalam penelitian ini berdasarkan tingkat pendidikan terakhir :

Tabel 3. Karakteristik Responden Berdasarkan Pendidikan Terakhir

\begin{tabular}{|c|c|c|c|}
\hline No & Pendidikan & Responden & Persentase $(\%)$ \\
\hline 1 & SLTP & 6 & 20,0 \\
\hline 2 & SMU & 24 & 80,0 \\
\hline & Total & 30 & 100 \\
\hline
\end{tabular}

Tabel 3 menunjukkan bahwa banyaknya responden berdasarkan tingkat pendidikan terakhir terbanyak adalah tingkat pendidikan terakhir SMU (sudah lulus dan sementara duduk dibangku perkuliahan) sebesar 80,0\%. Konsumen yang memiliki tingkat pendidikan terakhir SLTP (sudah lulus dan sementara duduk dibangku SMU) sebanyak 20,0\%. Berdasarkan dari hasil ini maka dapat diketahui bahwa konsumen terbanyak di What's Up Cafe Manado adalah lulusan SMU atau bisa dikatakakan kalangan mahasiswa. Hal ini disebabkan karena, gaya hidup mahasiswa yang gemar berkumpul dan makan.

\section{Berdasarkan Pekerjaan}

Karakteristik responden selanjutnya adalah berdasarkan pekerjaan. Data ini diperlukan untuk mengetahui berasal dari kalangan pekerjaan apa saja konsumen yang datang di What's Up Cafe Manado. Berikut ini adalah deskripsi responden dalam penelitian ini berdasarkan pekerjaan.

Tabel 4. Karakteristik Responden Berdasarkan Pekerjaan

\begin{tabular}{cccc}
\hline No & Pekerjaan & Responden & Persentase (\%) \\
\hline 1 & Pelajar & 6 & 20,0 \\
2 & Mahasiswa & 19 & 63,0 \\
3 & Wiraswasta & 5 & 17,0 \\
\hline & Total & $\mathbf{3 0}$ & $\mathbf{1 0 0}$
\end{tabular}

Sumber : Diolah dari data primer, 2019

Tabel 4 menunjukkan bahwa jumlah responden terbanyak bagi yang belum bekerja merupakan mahasiswa, yaitu 19 orang atau $63,0 \%$, diikuti oleh pelajar 6 orang atau $20,0 \%$, sedangkan bagi konsumen yang sudah bekerja merupakan wiraswasta sebanyak 5 orang atau $17,0 \%$. Hal ini disebabkan karena What's Up Cafe fokus kepada anak muda.

\section{Kepuasan Konsumen Terhadap Variabel Produk}

Produk mempengaruhi kepuasan konsumen karena merupakan sesuatu yang ditawarkan ke pasar untuk memenuhi kebutuhan dan keinginan konsumen. Pembeli akan membeli produk kalau merasa cocok, karena itu produk harus disesuaikan dengan keinginan ataupun kebutuhan pembeli agar pemasaran produk berhasil. Produk yang berkualitas dapat memuaskan konsumen. Konsumen akan merasa puas bila hasil evaluasi menunjukkan bahwa produk yang digunakan berkualitas. Persepsi konsumen terhadap pernyataan/pertanyaan yang menyebutkan variasi produk, dapat dilihat dari Tabel 5.

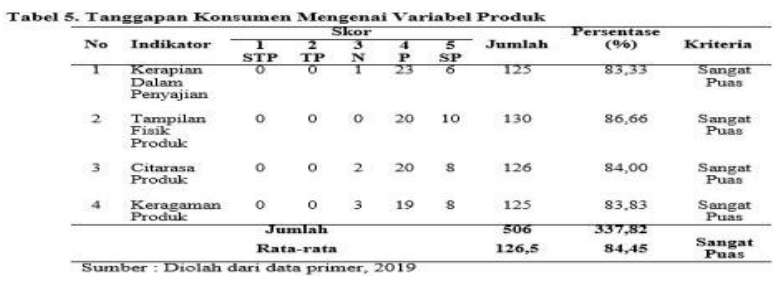


Tabel 5 menunjukkan bahwa rata-rata tanggapan konsumen pada variabel produk adalah $84,55 \%$ dengan kriteria sangat puas. Hal ini menunjukkan bahwa konsumen mendapatkan kepuasan dari produk tersebut. Indikator yang mendapatkan kepuasan konsumen lebih tinggi adalah tampilan fisik produk sebesar $86,66 \%$ dengan kriteria sangat puas. Hal ini disebabkan karena tampilan fisik produk yang menarik dan enak untuk dilihat. Oleh sebab itu What's Up Cafe Manado harus tetap mempertahankan tampilan fisik produk yang ditawarkan pada konsumen. Indikator cita rasa produk sebersar $84,00 \%$ dengan kriteria sangat puas hal ini menunjukkan bahwa konsumen merasa sangat puas. Indikator Keragaman produk sebesar 83,83\% dengan kriteria sangat puas menunjukkan bahwa memenuhi kepuasan konsumen. Indikator kebersihan dalam penyajian sebesar $83,33 \%$ dengan kriteria sangat puas menunjukkan kosumen sangat puas dengan hal penyajiannya.

\section{Kepuasan Konsumen Terhadap Variabel Harga Persepsi konsumen mengenai} pernyataan/pertanyaan yang menyebutkan variasi harga. Harga merupakan komponen penting atas suatu produk karena akan berpengaruh terhadap keuntungan produsen. Harga produk yang ditawarkan perusahaan kepada konsumen sangat mempengaruhi keputusan pembelian. Karena konsumen akan membandingkan harga yang ditawarkan dari satu produk dengan produk yang lainnya. Dapat dilihat dari Tabel 6 berikut.

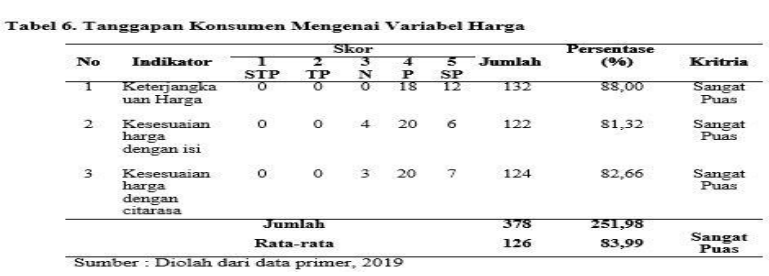

Tabel 6 menunjukkan bahwa rata-rata tanggapan responden terhadap harga jual produk sebanyak $83,99 \%$ dengan kriteria puas artinya harga yang ditetapkan sangat terjangkau dikantong masyarakat khususnya mahasiswa karena mayoritas konsumen What's Up cafe adalah mahasiswa. Skor yang paling tinggi ada pada indikator keterjangkauan harga sebesar $88.00 \%$ dengan kriteria sangat puas. Hal ini menunjukkan bahwa harga yang terjangkau sangat memuaskan konsumen. Indikator kesesuaian harga dengan cita rasa sebesar $82,66 \%$ dengan kriteria sangat puas menunjukkan bahwa konsumen merasa sangat puas. Indikator kesesuaian harga dengan isi sebesar $81,33 \%$ hal ini menunjukkan bahwa konsumen merasa sangat puas. Dalam menawarkan produk makanan haruslah disertai dengan harga jual yang sesuai dengan target konsumen dan kesesuaian harga adalah merupakan salah satu faktor yang menarik perhatian konsumen What's Up Cafe dalam mengkonsumsi produk yang ditawarkan.

\section{Kepuasan Konsumen Terhadap Variabel Tempat} Persepsi konsumen mengenai pernyataan/pertanyaan yang menyebutkan variabel tempat. Lokasi sangat berpengaruh terhadap keinginan konsumen untuk berkunjung dan berbelanja, sehingga seorang pengusaha akan selalu berusaha mencari lokasi strategis yang mudah dilihat dan dijangkau oleh konsumen. Lokasi yang strategis dapat menguntungkan produsen. Dapat dilihat pada Tabel 7 berikut.

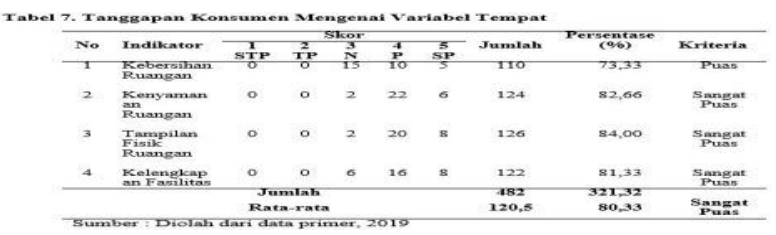

Tabel 7 menunjukkan bahwa kepuasan konsumen tertinggi variabel tempat dengan indikator tampilan fisik ruangan sebanyak $84,00 \%$ dengan kriteria sangat puas. Hal ini disebabkan karena desain interior dalam ruangan What's Up Cafe sangat menarik perhatian konsumen, suasana ruangan juga sangat mendukung untuk konsumen tetap nyaman berada dalam ruangan dan indah untuk dilihat. Indikator kenyamanan ruangan sebesar $82,66 \%$ dengan kriteria sangat puas menunjukkan bahwa konsumen sangat puas. Indikator kelengkapan fasilitas sebesar 81,33\% dengan kriteria sangat puas. Sedangkan indikator terendah kebersihan ruangan sebanyak 73,33\% dengan kriteria puas. Hal ini disebabkan karena karyawan tidak langsung membersihkan dan merapikan meja yang sudah konsumen tinggalkan sehingga terkesan kotor karena tidak langsung dibersihkan. Kemudian kebersihan dalam ruangan merupakan salah satu hal yang paling diinginkan oleh setiap konsumen pada saat mengunjungi sebuah usaha atau restoran. Jadi kebersihan dalam ruangan harus diperhatikan What's Up Cafe agar tetap bersih karena mempengaruhi konsumen yang akan berkunjung kembali.

\section{Kepuasan Konsumen Terhadap Variabel Pelayanan}

Pelayanan yang baik akan memberikan dorongan kepada konsumen untuk melakukan pembelian ulang diperusahaan tersebut. Pelayanan merupakan suatu tindakan yang 
dilakukan untuk memenuhi kebutuhan orang lain yang tingkat kepuasannya hanya dapat dirasakan oleh orang lain yang melayani maupun yang dilayani. Dengan kata lain pelayanan sangat berpengaruh pada kepuasan konsumen. Jadi selain produk yang baik harus diimbangi dengan pelayanan yang baik kepada konsumen. Persepsi konsumen mengenai pernyataan/pertanyaan yang menyebutkan variabel pelayanan dapat dilihat pada Tabel 8.

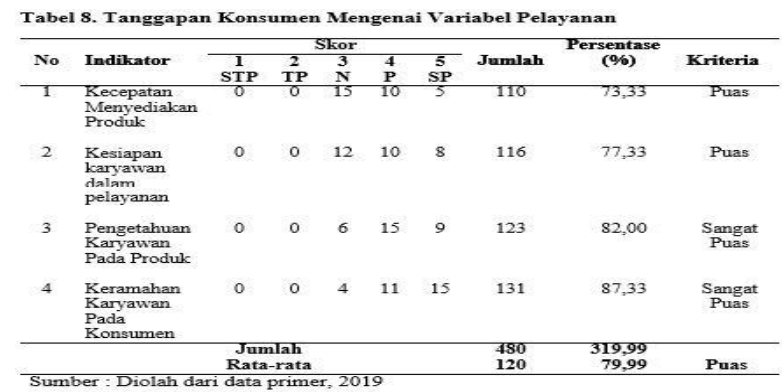

Tabel 8 menunjukkan bahwa rata-rata kepuasan konsumen pada variabel pelayanan adalah sebanyak $79,99 \%$ dengan kriteria lebih puas. Indikator pelayanan yang memiliki tingkat kepuasan tertinggi keramahan karyawan dalam menangani konsumen adalah sebanyak $87,33 \%$ dengan kriteria sangat puas. Hal ini disebabkan karena sikap karyawan yang ramah dalam melayani konsumen membuat konsumen senang dan merasa sangat puas. Indikator pengetahuan karyawan pada produk yang dijual sebesar $82,00 \%$ dengan kriteria sangat puas. Indikator kesiapan karyawan dalam memberikan pelayanan dan menangani keluhan para konsumen sebesar $77,33 \%$ dengan kriteria puas menunjukkan bahwa konsumen puas. Sedangkan indikator kecepatan dalam menyediakan produk yang memperoleh tingkat kepuasan konsumen terendah adalah sebanyak $73,33 \%$ dengan kriteria puas dengan alasan lamanya karyawan dalam menyediakan produk. Jadi konsumen menyatakan sangat puas pada keramahan dan kesopanan karyawan dalam menjelaskan produk.

\section{Rekapitulasi Kepuasan Konsumen What's Up Cafe Dari Variabel Produk, Harga, Tempat dan Pelayanan}

Penelitian ini mengukur tingkat kepuasan konsumen What's Up Café Manado dengan 15 indikator pertanyaan terhadap 30 responden. Berikut Tabel rekapitulasi kepuasan konsumen What's Up Cafe Manado dari variabel produk, harga, tempat, dan pelayanan.
Tabel 9. Rekapitulasi Total Skor Kepuasan Konsumen dan interpretasi

\begin{tabular}{ccccc}
\hline No & Variabel & $\begin{array}{c}\text { Total } \\
\text { Skor }\end{array}$ & $\begin{array}{c}\text { Indeks } \\
\text { Kepuasan (\%) }\end{array}$ & Interpretasi \\
\hline 1 & Produk & 506 & $84,45 \%$ & Sangat Puas \\
2 & Harga & 378 & $83,99 \%$ & Sangat Puas \\
3 & Tempat & 482 & $80,33 \%$ & Sangat Puas \\
4 & Pelayanan & 480 & $79,99 \%$ & Puas \\
\hline \multicolumn{5}{l}{ Sumber : Diolah dari data primer, 2019}
\end{tabular}

Tabel 9 menunjukkan bahwa total skor variabel produk sebesar 506 dengan indeks kepuasan konsumen $84,45 \%$ dengan interpretasi sangat puas. Skor variabel harga 378 dengan indeks kepuasan konsumen 83,99\% dengan interpretasi sangat puas. Skor variabel tempat sebesar 482 dengan indeks kepuasann konsumen $80,33 \%$ dengan interpretasi sangat puas. Selanjutnya skor variabel pelayanan sebesar 480 dengan indeks kepuasan konsumen 79,99\% dengan interpretasi puas.

Jumlah skor ideal untuk semua pertanyaan adalah 2.250 (sangat puas), jumlah skor terendah adalah 450 (sangat tidak puas). Berdasarkan data yang diperoleh dari 15 pertanyaan yang diberikan kepada 30 responden, maka diperoleh total skor 1.846 , dengan indeks kepuasan konsumen pengunjung sebagai berikut.

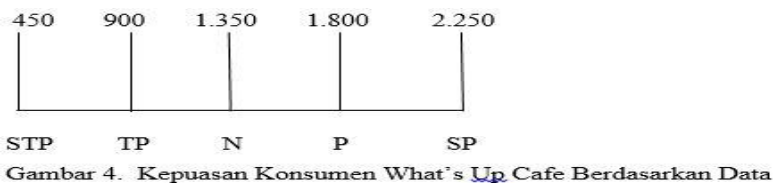

Secara persentase, kepuasan konsumen What's Up Cafe adalah sebagai berikut:

$$
\begin{gathered}
I K K=\frac{1.846}{2.250} \times 100 \% \\
=82.04 \%
\end{gathered}
$$

Dengan interpretasi nilai :

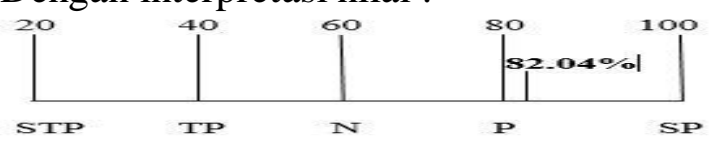

Gambar 5. Kepuasan Konsumen What's Up Cafe Berdasarkan Persentase

Berdasarkan Hasil analisis menggunakan Skala Likert, maka dapat diketahui bahwa angka indeks kepuasan konsumen What's Up Cafe dari variabel produk, harga, tempat dan pelayanan sebesar $82.04 \%$ artinya secara umum konsumen tergolong sangat puas. Hal ini menunjukkan secara keseluruhan What's Up Cafe telah memberikan kepuasan yang tinggi kepada konsumen walaupun ada beberapa indikator yang harus diperhatikan dan ditingkatkan lagi.

Pengambilan data keseluruhan terdapat 4 variabel yang dinilai oleh konsumen What's Up Cafe yaitu dari variabel produk, harga, tempat, dan pelayanan. Dari 4 variabel tersebut yang memiliki tingkat kepuasan konsumen yang paling tinggi yaitu variabel produk sebesar 84,45 . 


\section{KESIMPULAN DAN SARAN}

\section{Kesimpulan}

Tingkat kepuasan konsumen What's Up Cafe Manado berdasarkan variabel produk, harga, dan tempat memberikan tingkat kepuasan yang sangat tinggi. Namun demikian What's Up Cafe harus meningkatkan pelayanan terhadap konsumen.

\section{Saran}

Perlu ditingkatkan pelayanan. Kecepatan menyediakan produk dan kesiapan karyawan dalam pelayanan.

\section{DAFTAR PUSTAKA}

Giese, J. L., and J. A. Cote. 2000. Defining Consumer Satisfaction, Academy of Marketing Science Review, no. 1, pp. 1-24. PT. Gramedia, Jakarta.

Kotler, 2004. Manajemen Pemasaran, Edisi Milenium, Jilid I, PT Prenhallindo, Jakarta.
Kotler, Philip. 2000. Manajemen Pemasaran (Terjemahan, Jilid I dan II). PT. Elex Media Komputindo, Jakarta.

Nasution, M. N. 2005. Reformasi Birokrasi : Peningkatan Mutu Pelayanan Publik. Universitas Diponegoro, Semarang.

Rahayu, 2005. "Analisis Faktor-Faktor yang Mempengaruhi Tingkat Kepuasan PT Lion Air" (Tesis). Surakarta: Program Pascasarjana Universitas Muhammadiyah Surakarta.

Tjiptono, F dan Chandra, G. 2005.

Pemasaran Strategik; Ed. II. C. V. Andi Offset, Yogyakarta.

Tjiptono, Fandy dan Gregorius Chandra, 2012. Pemasaran Strategik. Yogyakarta. ANDI. 